\title{
Use of $0.1 \%$ chlorine dioxide to inhibit the formation of morning volatile sulphur compounds (VSC)
}

\author{
Uso do enxaguatório de dióxido de cloro \\ a $0,1 \%$ para inibir a formação matinal de \\ compostos sulfurosos voláteis (CSV)
}

\section{Daiane Cristina Peruzzo(a) Priscila Fontoura Castelo Branco Jandiroba $^{(b)}$}

Getulio da Rocha Nogueira Filho(c)

(a) PhD Student; (c) Professor - Department of Prosthodontics and Periodontics, School of Dentistry of Piracicaba, State University of Campinas.

(b) Dental Student, Bahia Foundation for the Development of Sciences (Fundação Bahiana para o Desenvolvimento das Ciências).

\section{Corresponding author:}

Daiane Cristina Peruzzo

Av. Evandro Batista Vieira, 775/13

Campinas - SP - Brazil - CEP: 13098-390

E-mail:daiaperuzzo@yahoo.com.br

Received for publication on Apr 04, 2006 Sent for alterations on Jul 21, 2006

Accepted for publication on Sep 29, 2006

\begin{abstract}
The aim of this study was to evaluate the VSC-inhibiting effect of a commercially available mouthrinse $(0.1 \%$ chlorine dioxide) when compared to its placebo. A 2step double blind, crossover, randomised study was conducted with 14 dental students with healthy periodontium, who refrained from any mechanical plaque and tongue coating control during two 4-day experimental periods. The subjects were instructed to rinse 3 times daily with the assigned product during each period. A 7-day washout interval was established. VSCs levels were measured by a sulphide monitor at the beginning (baseline) and at the end of each experimental period. Statistical analyses were performed using Wilcoxon's and Mann-Whitney's non-parametric tests. At baseline, intragroup analysis revealed that VSCs levels did not differ between groups ( $\mathrm{p}>0.05$ ); at day 5, the use of the chlorine dioxide mouthrinse did not change the baseline VSCs scores in the control group ( $p>0.05$ ), while a 2 -fold increase was observed with the use of the placebo mouthrinse $(\mathrm{p}<0.05)$. Intergroup analysis showed a significant difference between the VSCs levels of the test and control groups $(40.2 \pm 30.72$ and $82.3 \pm 75.63 \mathrm{ppb}, \mathrm{p}<0.001)$ at day 5 . Within the limits of this study, the findings suggest that a mouthrinse containing chlorine dioxide can maintain VSCs at lower levels in the morning breath.
\end{abstract}

Descriptors: Mouthwashes; Halitosis; Chlorine dioxide.

Resumo: O objetivo do presente estudo foi avaliar o efeito inibitório do enxaguatório de dióxido de cloro a $0,1 \%$ sobre a formação dos CSVs, quando comparados a um placebo. Um estudo randomizado, cruzado, duplo cego foi conduzido com 14 estudantes de odontologia apresentando saúde periodontal, os quais se abstiveram dos hábitos de escovação dentária e limpeza da língua durante dois períodos experimentais de 4 dias. Os voluntários foram orientados a utilizar o enxaguatório designado 3 vezes ao dia conforme indicado no rótulo. Um intervalo de 7 dias foi estabelecido entre os períodos experimentais. No início ("baseline") e no final de cada período experimental, os níveis de CSVs foram medidos com o uso do monitor de sulfetos. Análise estatística foi realizada utilizando-se os testes não-paramétricos de Wilcoxon e Mann-Whitney. No "baseline”, uma análise intragrupo revelou que os níveis de CSVs não diferiram entre os grupos ( $\mathrm{p}>0.05$ ); no dia 5, o uso do dióxido de cloro não promoveu mudanças significativas nos níveis de CSVs em relação ao "baseline" no grupo controle ( $p>0,05)$, entretanto os níveis de CSVs duplicaram com a utilização enxaguatório placebo $(\mathrm{p}<0,05)$. Uma análise entre os grupos teste e controle revelou diferença significante para os níveis de CSVs $(40,2 \pm 30,72$ e 82,3 \pm 75,63 ppb, $\mathrm{p}<0,001)$ no dia 5. Dentro dos limites deste estudo, os achados sugerem que o uso de enxaguatórios contendo dióxido de cloro pode promover a manutenção de baixos níveis de CSVs no hálito matinal.

Descritores: Anti-sépticos bucais; Halitose; Dióxido de cloro. 


\section{Introduction}

The etiology of halitosis involves many intra- and extra-oral factors such as gingivitis, periodontitis, nasal inflammation, chronic sinusitis, diabetes mellitus, liver insufficiency, cirrhosis, uremia, lung carcinoma, trimethylaminuria and post nasal drip..$^{15,17,26}$ Nevertheless, representative epidemiological reports ${ }^{6}$ have reported that around $87 \%$ of the bad breath cases have oral causes, whereas only $5-8 \%$ of the cases can be attributed to ear, nose and throat causes.

Considering the relevance of the oral etiological aspects of halitosis, recent reports have been designed to verify the real efficacy of some products such as toothpastes and mouthrinses containing antimicrobial agents that are claimed to produce a reduction on bad breath. ${ }^{5,15,16,24,26}$ Moreover, not only the antimicrobial capacity of these products, but also the oxidative biochemical effect on volatile sulphur compounds (VSCs) has been investigated. ${ }^{22}$

The clinical use of mouthrinses containing chlorine dioxide has been reported to reduce oral malodour by the control of VSCs. ${ }^{8,9}$ Experimentally, the use of chlorine dioxide associated with chlorite anion has been shown to result in oxidative consumption of amino acids like cysteine and methionine, which are precursors of VSCs. ${ }^{14}$ Thus, clinical use of this mouthrinse can be expected to reduce oral malodor by reducing concentrations of VSCs. Chlorine dioxide, a strong oxidizing agent, consumes oral substrates containing cysteine and methionine, thus preventing the production of VSCs. Since chlorine dioxide readily loses its activity, its stability has been prolonged through a "stabilization" process, which converts chlorine dioxide to molecular chlorine dioxide at a low $\mathrm{pH} .{ }^{8,9}$

There is a lack, however, of controlled clinical trials conducted in order to prove the effectiveness of this formula. Thus, the aim of this study was to evaluate the inhibiting effect of a commercially available chlorine dioxide mouthwash on VSC levels in a panel of healthy subjects.

\section{Materials and Methods Patient population}

Fourteen dental students ( 6 female and 8 male; aged 18-25 years) volunteered to participate in this study. The Institutional Committee of Ethics in Clinical Research,
State University of Campinas (UNICAMP), approved the study protocol. The exclusion criteria were: subjects with medical disorders, undergoing antibiotic or other antimicrobial therapy, smokers, and pregnant women. In addition, the participants in the study should present a normal salivary flow rate $(1.5-2.5 \mathrm{ml})$ and at least 20 teeth that did not present gingival probing depths greater than $3 \mathrm{~mm}$ and gingival indexes ${ }^{2}$ and plaque indexes $^{2}$ equal to 1 in more than $10 \%$ of the sites (considering $0=$ no plaque and $1=$ plaque present).

\section{Study design}

This study was a randomized, double blind, placebo-controlled clinical trial of 14 volunteers divided (by a coin tossing) into two crossover groups, and it was performed in two experimental periods of 4 days. A 7-day washout interval was established between the treatment periods. The 4 -day plaque regrowth experimental model was adopted, ${ }^{1}$ where mechanical plaque and tongue coating removal was avoided during this period.

\section{Pre-experimental phase}

A 15-day pre-experimental phase occurred, where the subjects used a dentifrice without antimicrobial agents $\left(\right.$ Sorriso $^{\circledR}$, Anakol Ind. Com. Ltda. Kolynos do Brasil - Colgate Palmolive Co., São Bernardo do Campo, SP, Brazil). Baseline data on dental plaque $\left(\mathrm{PI}^{2}\right)$ and gingival $\left(\mathrm{GI}^{2}\right)$ indices were recorded in order to exclude volunteers with periodontal disease, following the exclusion criteria.

\section{Test and control products}

Commercial mouthrinse samples containing 0.1\% chlorine dioxide $\left(\right.$ SaudBucal ${ }^{\circledast}$, Saudbucal ${ }^{\circledR}$ Project, São Paulo, Brazil) were bought in the marketplace and transferred to identical, codified bottles to ensure blindness of the study. A placebo of the SaudBucal ${ }^{\circledR}$ mouthrinse was provided by the Saudbucal ${ }^{\circledR}$ Project (São Paulo, SP, Brazil) that contained the same compounds of the test mouthrinse with the exception of the active principle (chlorine dioxide). Both mouthrinse samples (test and placebo) were placed, by the maker, in new plastic, coded recipients in such a way that direct identification of the product was impossible. The codes were not disclosed until the study had been completed. 


\section{Experimental phase}

On day 1 of each treatment period, all hygiene procedures were suspended for the following 4 days, except for the use of the mouthrinses assigned to the volunteers according to the experimental group. After measurement of VSCs, the 14 volunteers underwent a scaling and polishing procedure to remove all plaque, calculus and stain. Professional tongue cleaning was also performed in order to eliminate any remaining tongue coating. No oral hygiene instructions were given, according to the experimental protocol. The volunteers were instructed to rinse for 1 minute and gargle for the last 10 seconds, three times daily, with $15 \mathrm{ml}$ of the assigned product during the 4-day period. During the washout interval, a control dentifrice $\left(\right.$ Sorriso $^{\circledR}{ }^{\circledR}$ Colgate-Palmolive, São Paulo, SP) was used with a new toothbrush to avoid any carry-over effect.

\section{Morning breath evaluation}

At the beginning and at the end of all experimental periods, VSCs concentrations were recorded using a portable industrial sulphide monitor (Halimeter ${ }^{\circledR}$, Interscan Corp., Chatsworth, CA), zeroed on ambient air before each measurement using the technique established by Rosenberg et al. ${ }^{20,21}$ (1991). The data were recorded before rinsing at 8 a.m. (day 1), and twelve hours after the last rinse (day 5). The measurement was repeated three times for each subject. Before the morning measurements ( 8 a.m.) on day 1 and 5, the volunteers refrained from toothbrushing, drinking, eating, gargling and using scented cosmetic products. ${ }^{19}$ As an ethical conduct, a breakfast was offered to the volunteers after the analysis.

\section{Analysis of the data}

The Kolmogorov-Smirnov test was used to verify the normality of the data and two non-parametric tests were used. According to the crossover design, Mann-Whitney test was used for intergroup analysis. The Wilcoxon test was applied to the intragroup data, completing the comparisons between VSCs scores on day 1 and 5. The percentage of change was calculated by:

[(VSC concentration before - VSC concentration after $) \times$ 100] / VSC concentration before
For all the analyses, a 5\% significance level was set and the data were analyzed using the software BioEstat 2.0.3

\section{Results Intragroup analysis}

Comparison between the VSCs levels at baseline and after a 4-day period of total absence of mechanical plaque control revealed that the $0.1 \%$ chlorine dioxide mouthrinse produced no significant reduction $(\mathrm{p}=0.48)$ in VSC formation. However, a 2-fold increase in VSCs was observed with the use of the placebo $(\mathrm{p}=0.03)$. These data are presented in Table 1 .

\section{Intergroup analysis}

There were no statistically significant differences $(p>0.05)$ in the VSC scores among the fourteen volunteers at the beginning of each experimental period (Table 1). Nevertheless, comparison between the treatments at day 5 showed a statistical difference, which was related to the increased VSCs levels in the placebo group and not due to an alteration in the chlorine dioxide group.

\section{Discussion}

In order to reduce bad breath, two approaches have been used and tested in the literature: cleaning the tongue and tooth surfaces by physical methods and/or reducing the bacterial loads by chemical agents present in dentifrices and mouthrinses. ${ }^{5,16,18,24}$ Thus, the aim of this study was to evaluate the effect of a commercially available chlorine dioxide mouthrinse on VSCs levels in a panel of healthy subjects. The results of the present investigation dem-

Table 1 - Volatile sulphur compounds (VSC) concentration (ppb) before and after the treatments and percentage of change (\%C VSC) before and after each treatment (mean $\pm \mathrm{SD} ; \mathrm{n}=14$ ).

\begin{tabular}{l|c|c|c}
\hline \multirow{2}{*}{ Treatments } & \multicolumn{2}{|c|}{ VSC } & \multirow{2}{*}{$\%$ C VSC } \\
\cline { 2 - 4 } & Before & After & \\
\hline Placebo & $38.7 \pm 44.08 \mathrm{aA}$ & $82.3 \pm 75.63 \mathrm{aB}$ & $112.9 \mathrm{a}$ \\
\hline Chlorine dioxide & $45.7 \pm 41.12 \mathrm{aA}$ & $40.2 \pm 30.72 \mathrm{bA}$ & $-12 \mathrm{~b}$ \\
\hline
\end{tabular}

Means followed by distinct lower case letters in columns differ statistically $(p<0.05)$. Means followed by distinct capital letters in lines differ statistically ( $p<0.05)$. VSC: Volatile Sulphur Compounds; \% C VSC: percentage of change in VSC level. 
onstrated a beneficial effect of a chlorine dioxide mouthrinse on VSC control in the morning breath of healthy subjects when compared with its own placebo. This study used a sample of 14 subjects, which was similar to that used in the study of Carvalho et al. ${ }^{5}$ (2004), who used 12 subjects to evaluate the morning bad breath-inhibiting effect of four commercially available mouthrinses. The sample size used in that study was sufficient to reveal statistical differences. In future studies, if a bigger sample is used it is possible that a statistical difference will be found between the evaluation periods.

Previous studies have shown the positive effects of chlorine dioxide on the inhibition of VSC formation, ${ }^{8,9}$ which is in agreement with our results. Interestingly, the intergroup analysis of this study showed a 2-fold increase in VSC levels with the use of the placebo mouthrinse, and this may suggest that the placebo itself was not capable of controlling VSCs.

In a recent investigation, our group demonstrated the beneficial impact of mouthrinses on morning breath in the absence of mechanical plaque control. ${ }^{5}$ Comparatively, the use of commercial mouthrinses containing essential oils (Listerine $\left.{ }^{\circledR}\right), 0.03 \%$ triclosan $\left(\operatorname{Plax}^{\circledR}\right)$ and cetylpyridinium chloride $\left(\mathrm{Cepacol}^{\circledR}\right)$ did not prove to be more effective than the chlorhexidine ones in reducing VSCs. Notwithstanding, the use of a negative control mouthrinse increased VSC formation, corroborating the present findings with the use of a placebo mouthrinse.

According to Rosenberg et al. ${ }^{20}$ (1991), there is a significant correlation between the odor scores measured by judges (organoleptic assays) and the VSC levels recorded by a sulphide monitor. Goldberg et al. ${ }^{10}$ (1994) also reported that, in addition to the sulphurous compounds $\left(\mathrm{H}_{2} \mathrm{~S}\right.$ and $\left.\mathrm{CH}_{3} \mathrm{SH}\right)$ measured by the sulphide monitor, there are other foul smelling elements that are not captured by the monitor, and may be perceived by the human olfactory sense and not detected by the monitor. However, in the present study, the aim was to evaluate only the VSC levels, and for that purpose the sulphide monitor was used.

Previous studies have shown that chlorhexidine mouthrinses are the gold standard for VSC formation. ${ }^{11,21,26}$ However, the chlorhexidine control was not used in the present study because the main purpose was to observe the cosmetic aspect of the chlo- ride dioxide mouthrinse. Nevertheless, the authors agree that a further comparative study is required.

The present investigation did not reveal statistical differences between days 1 and 5 for VSC formation when the chlorine dioxide mouthrinse was used, even after plaque and tongue coating removal. Periodontal disease can be a factor in chronic halitosis. ${ }^{15,25}$ It is also well documented that the tongue surface is another strong odour formative site in the mouth. ${ }^{13}$ As a matter of fact, a substantial proportion of healthy people may complain of oral malodour. ${ }^{4}$ Nevertheless, a discussion could be raised about the stabilization of the VSC levels and its correlation with tongue coating and periodontal disease versus the reduction of oral microbiota itself in oral niches like tongue, teeth, mucous membrane surfaces and saliva.

Indeed, there is ample evidence in the literature that the presence of tongue coating or periodontal disease $e^{7,15,25}$ is related with bad breath. Miyazaki et al. ${ }^{13}$ (1995) evaluated oral malodor using a portable sulphide monitor, and observed a high correlation between VSCs and tongue coating. Yaegaki, Sanada ${ }^{28}$ (1992) found that removal of tongue coating markedly reduced VSC production, and also demonstrated that the concentrations of hydrogen sulphide and methyl mercaptan in mouth air were higher in patients with probing depths greater than $4 \mathrm{~mm}$ than in healthy individuals. In summary, if the tongue coating is removed and periodontal disease is controlled, bad breath will be reduced. ${ }^{17}$ And this treatment outcome can even be improved by additional plaque control. ${ }^{23}$

The population in general has a major concern that leads to frequent use of mouthrinses to prevent halitosis. ${ }^{27}$ According to Loesche ${ }^{12}$ (1999), in early clinical trials of antimalodor mouthrinses, they have been designed both as a drug and as a cosmetic product. Consequently, considering bad breath in healthy subjects as a cosmetic problem that is analogous to body malodour, all products that are claimed to be effective cosmetics endure the scrutiny of the marketplace, and only those of merit should survive.

\section{Conclusion}

Within the limits of this study, the findings suggest that a mouthrinse containing chlorine dioxide seems to maintain VSCs at lower levels in the morning 
breath when compared with a placebo mouthrinse.

\section{Acknowledgements}

The authors wish to thank the students from the School of Dentistry, FDC (Bahia Foundation for the

\section{References}

1. Addy M, Willis L, Moran J. Effect of toothpaste rinses compared with clorhexidine on plaque formation during a 4-day period. J Clin Periodontol. 1983;10(1):89-99.

2. Ainamo J, Bay I. Problems and proposals for recording gingivitis and plaque. Int Dent J. 1975;25(4):229-35.

3. Ayres M, Ayres M Jr, Ayres DL, Santos AS. BioEstat 2.0: Statistical applications in Biological Sciences and Medicine. Belém, Brasília: CNPq; 1998.

4. Bosy A, Kulkarni GV, Rosenberg M, Mc Culloch CA. Relationship of oral malodor to periodontitis: evidence of independence in discrete subpopulations. J Periodontol. 1994;65(1):37-46.

5. Carvalho MD, Tabchoury CM, Cury JA, Toledo S, NogueiraFilho GR. Impact of mouthrinses on morning bad breath in healthy subjects. J Clin Periodontol. 2004;31(2):85-90.

6. Delanghe G, Ghyselen J, Bollen C, van Steenbergue D, Vanderkerckhove BN, Feenstra L. An inventory of patients' response to treatment at a multidisciplinary breath odor clinic. Quintessence Int. 1999;30(5):307-10.

7. Figueiredo LC, Rosetti EP, Marcantonio E Jr, Marcantonio RA, Salvador SL. The relationship of oral malodor in patients with or without periodontal disease. J Periodontol. 2002;73(11):1338-42.

8. Frascella J, Gilbert R, Fernandez P. Odour reduction potential of a chlorine dioxide mouthrinse. J Clin Dent. 1998;9(2):39-42.

9. Frascella J, Gilbert RD, Fernandez P, Hendler J. Efficacy of chlorine dioxide-containing mouthrinse in oral malodor. Compend Contin Educ Dent. 2000;21(3):241-4, 246, 248 passim; quiz 256.

10. Goldberg S, Kozlovsky D, Gordon D, Gelernter I, Sintov A, Rosenberg M. Cadaverine as a putative component of oral malodor. J Dent Res. 1994;73(6):1168-72.

11. Kozlovsky A, Goldberg S, Natour I, Rogatky-Gat A, Gelernter I, Rosenberg M. Efficacy of a 2-Phase Oil: water Mouthrinse in Controlling Oral Malodor, Gingivitis, and Plaque. J Periodontol. 1996;67(5):577-82.

12. Loesche WJ. The effects of antimicrobial mouthrinses on oral malodor and their status relative to US Food and Drug Administration regulations. Quintessence Int. 1999;30(5):311-8.

13. Miyazaki H, Sakao S, Katoh Y, Takehara T. Correlation between volatile sulphur compounds and certain oral health measurements in the general population. J Periodontol. 1995;66(8):679-84.

14. Nachnani S. The effects of oral rinses on halitosis. J Calef
Development of Sciences), who participated in the study, and the Saudbucal ${ }^{\circledR}$ Project (São Paulo, Brazil) for providing the placebo and test products. This investigation was financially supported by The State of Bahia Research Foundation (FAPESB, \#069/002).

Dent Assoc. 1997;25(2):145-50.

15. Nogueira-Filho GR, Duarte PM, Toledo S, Tabchoury COM, Cury JA. Effect of triclosan dentifrices on mouth volatile sulphur compounds and dental plaque trypsin-like activity during experimental gingivitis development. J Clin Periodontol. 2002;29(12):1067-73.

16. Peruzzo DC, Silva-Filho WLS, Salvador SL, Sallum AW, Nogueira-Filho GR. Correlação entre as medidas de compostos sulfurados voláteis (CSV) no hálito matinal e o teste BANA de saburra lingual. Rev Periodontia. 2006;16(2):14-9.

17. Preti G, Lawley HD, Hormamm CA, Cowart BJ, Feldman RS, Lowry LD et al. Non-oral and oral aspects of oral malodor. In: Rosenberg M. Bad Breath: Research Perspectives. Tel Aviv: Ramot; 1995. p. 149-73.

18. Roldan S, Herrera D, Sanz M. Biofilms and the tongue: therapeutical approaches for the control of halitosis. Clin Oral Invest. 2003;7(4):189-97.

19. Rosenberg M. Clinical Assessment of bad breath: current concepts. J Am Dent Assoc. 1996;127(4):475-82.

20. Rosenberg M, Kulkarni GV, Bosy A, McCulloch CA. Reproducibility and sensitivity of oral malodor measurements with a portable sulphide monitor. J Dent Res. 1991;70(11):1436-40.

21. Rosenberg M, Septon I, Eli I, Brenner S, Gelernter I, Gabbay J. Halitosis measurement by an industrial sulphide monitor. J Periodontol. 1991;62(8):487-9.

22. Rösing CK, Jonski G, Rolla G. Comparative analyses of some mouthrinses on the production of volatile sulfur-containing compounds. Acta Odontol Scand. 2002;60(1):10-2.

23. Seemann R, Kison A, Bizhang M, Zimmer S. Effectiveness of mechanical tongue cleaning on oral levels of volatile sulfur compounds. J Am Dent Assoc. 2001;132(9):1263-7

24. Silwood CJ, Grootveld MC, Lynch E. A multifactorial investigation of the ability of oral health care products (OHCPs) to alleviate oral malodour. J Clin Periodontol. 2001;28(7):634-41.

25. Söder B, Johansson B, Söder PO. The relation between foetor ex ore, oral hygiene and periodontal disease. Swed Dent J. 2000;24(3):73-82.

26. van Steenberghe D. Breath malodor. Curr Opin Periodontol. 1997;4(9):137-43.

27. Weenstrom JL. Mouthrinses in "experimental gingivitis" studies. J Clin Periodontol. 1988;15(5):511-6.

28. Yaegaki K, Sanada K. Volatile sulfur compounds in mouth air from clinically healthy subjects and patients with periodontal disease. J Periodontal Res. 1992;27(4 Pt 1):233-8. 